\section{Effect of Dry and Wet Storage at Different Temperatures on the Vase Life of Cut Flowers}

\author{
Juan-Carlos Cevallos ${ }^{1}$ and \\ Michael S. Reid ${ }^{2}$
}

A floriculture, postharvest, water relations

Stmary. After storage at different temperatures for a simulated transportation period, the vase lives at 20 ${ }^{\circ} \mathrm{C}\left(68{ }^{\circ} \mathrm{F}\right)$ of carnations (Dianthus caryophyllus 'Imperial White'), daffodils (Narcissus pseudonarcissus 'King Alfred'), iris (Iris bollandica 'Telstar'), killian daisies (Chrysanthemum maximum), paperwhite narcissus (Narcissus tazetta 'Paperwhite'), roses (Rosa ${ }_{(X t i m e x)}$ bybrida 'Ambiance'), and tulips (Tulipa gesneriana)

decreased with increasing storage temperature. There were no significant differences between the vase life of flowers stored dry and flowers stored in water when storage temperatures were from 0 to $10{ }^{\circ} \mathrm{C}$ ( 32 to 50 $\left.{ }^{\circ} \mathrm{F}\right)$. The vase life after wet storage at temperatures of $12.5^{\circ} \mathrm{C}\left(54.5^{\circ} \mathrm{F}\right)$ and greater was significantly higher than vase life after dry storage at those temperatures for all the flowers studied. Iris and carnation flowers survived storage at 15 and $20{ }^{\circ} \mathrm{C}$ (59 and $68{ }^{\circ} \mathrm{F}$ ) only when stored in water.

Department of Environmental Horticulture, University of California, Davis, CA 95616.

This paper is a portion of a thesis submitted by Juan Carlos Cevallos toward the degree of Master of Science in Horticulture. This work was partially supported by the California Cut Flower Commission and the American Floral Endowment. The authors thank Bill Suyeyasu Wholesale Florist and Consorcio Quitoflores S.A., Quito, Ecuador, for donating some of the plant material used in this research. We gratefully acknowledge the skilled technical assistance of Linda Dodge and Rosa Valle. Reference to a firm or trade name does not imply endorsement over firms or products not mentioned. The cost of publishing this paper was defrayed in part by the payment of page charges. Under postal regulations, this paper therefore must be hereby marked advertisement solely to indicate this fact.

${ }^{1}$ Graduate student.

${ }^{2}$ Professor and extension specialist.
$\mathrm{M}$ onitoring of transit temperatures of commercial cut flowers has shown that flowers are often exposed to damaging high temperatures. Maxie et al. (1974) and Thompson and Reid (1994) recorded flower temperatures above $27^{\circ} \mathrm{C}\left(81^{\circ} \mathrm{F}\right)$ in commercial flower shipments. Poor temperature management during transport of cut flowers is largely the result of inadequate precooling and transport under nonrefrigerated conditions. Several researchers have shown the negative effects of improper storage temperatures on vase life of a range of cut flowers (Cevallos and Reid, 2001). The poor arrival quality of transported cut flowers has spurred the development of systems like the Procona buckets (Pagter Innovations, Dinteloord, The Netherlands) in which the flowers are transported in water. Industry leaders have claimed a considerable improvement in postharvest quality for flowers transported in this way, and these claims have reduced the industry's emphasis on proper postharvest temperature management. Warm storage temperatures accelerate water loss, so it is possible that wet storage helps by replacing lost water. However, we have shown that reduction of cut flower vase life during storage is highly correlated with respiration at the storage temperature (Cevallos and Reid, 1999). A substantial reduction in the vase life of flowers shipped at warmer temperatures would therefore be expected even if they were shipped in water.

In the study reported here, several cut flower species were used to test the hypothesis that wet storage would have a beneficial effect on vase life only when flowers were held at warmer temperatures.

\section{Materials and methods}

Ptanf-haterhat: 'King Alfred' daffodils, killian daisies, paperwhite narcissus, and tulips were obtained from a wholesale florist (Bill Suyeyasu Florist, Fremont, Calif., and transported dry under refrigeration to Davis, Calif. 'Ambiance' roses were air-freighted, dry, directly from a wholesale grower/shipper (Consorcio Quitoflores, Quito, Ecuador). 'Imperial White' carnations and 'Telstar' iris were obtained from Kitayama Nurseries (Watsonville, Calif.) and transported in water to Davis, Calif.

Storage:expermate: On receipt, the 
flowers were unpacked, recut under deionized water to a length of $15 \mathrm{~cm}$ (6 inches) below the head or lowest bud and placed at storage temperatures ranging from 0 to $20^{\circ} \mathrm{C}$ for $6 \mathrm{~d}$. Twelve replicate stems of each type of flower were placed at each temperature. Six of them were wrapped in newspaper and perforated polyethylene and stored dry inside a fiberboard box and the remaining six were stored with their stems in deionized water containing $50 \mathrm{mg} \cdot \mathrm{L}^{-1}(\mathrm{ppm})$ sodium hypochlorite $(\mathrm{NaOCl})$.

Đeteramatron-ef-Hase-tefe: After storage, the flowers were recut under water to a stem length of $10 \mathrm{~cm}$ ( 4 inches) and
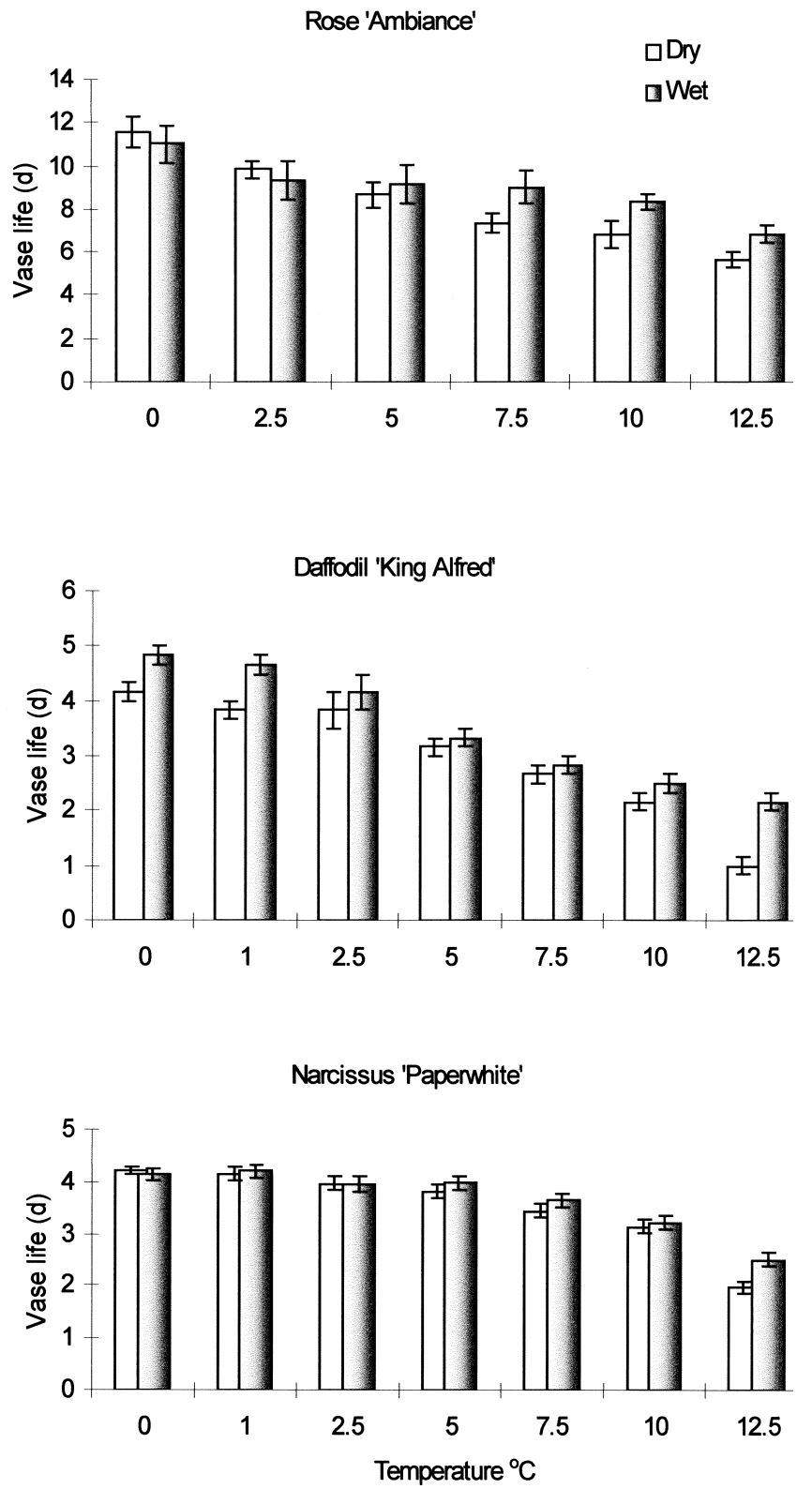

Fig. 1. Vase life of different flowers at $20^{\circ} \mathrm{C}\left(68^{\circ} \mathrm{F}\right)$ after $6 \mathrm{~d}$ of wet or dry storage at different temperatures. Error bars indicate the standard error of the means of six stems per treatment. placed in deionized water containing 50 $\mathrm{mg} \cdot \mathrm{L}^{-1} \mathrm{NaOCl}$ in a controlled-environment vase life evaluation room. The controlled environment was kept at a temperature of $20{ }^{\circ} \mathrm{C}$ and a relative humidity of about $60 \%$. Artificial light $\left(15 \mu \mathrm{mol} \cdot \mathrm{m}^{-2} \cdot \mathrm{s}^{-1} \mathrm{PAR}\right)$ was provided for $12 \mathrm{~h}$ each day by cool-white fluorescent tubes (Sylvania Lighting Co., Danvers, Mass.). The flowers were evaluated three times daily and vase life was recorded as the time taken for loss of aesthetic value.

Statisticat-ANatysis: The standard error of the mean vase life of the six replicate flowers in each treatment was determined.
Results and discussion Effect of temperature on vase life

Whether the flowers were stored dry or wet, the vase life at $20^{\circ} \mathrm{C}$ of all the flowers declined as the temperature during storage increased (Figs l, $2,3)$. The effect of storage temperature on vase life differed, even in closely related species, with daffodils showing a more rapid drop than paperwhites (Fig. 1). Iris flowers were most affected by the storage temperature (Fig. 3 ), and killian daisies (Fig. 2) were the least affected.

Effect of dry and wet storage

Rese'Aamiance' Vase life (determined as days to petal desiccation, wrinkling and loss of turgidity) was slightly but significantly higher after wet storage than after dry storage at storage temperatures above $5{ }^{\circ} \mathrm{C}(41$ $\left.{ }^{\circ} \mathrm{F}\right)$ (Fig. 1).

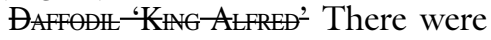
no significant differences in the vase life (determined as days to wilting of the perianth) after storage of daffodils dry or wet except for those stored at 12.5 ${ }^{\circ} \mathrm{C}$, the highest temperature tested (Fig. 1). Vase life after wet storage at $12.5^{\circ} \mathrm{C}$ was more than double that after dry storage at that temperature.

NAReissus-'PAPERWHImE' There were no significant differences in the vase life (days to senescence of $50 \%$ of the flowers on the scape) after dry or wet storage of narcissus except for a slightly longer vase life for those stored wet at $12.5^{\circ} \mathrm{C}$, the highest temperature tested (Fig. 1).

KHetanĐaisy Vase life (determined by petal browning and loss of turgidity) was not significantly different after wet storage than after dry storage at $0^{\circ} \mathrm{C}$ but was slightly better for wet-stored flowers after storage at $12.5^{\circ} \mathrm{C}$ (Fig. 2).

FutrP Vase life (days to petal desiccation and abscission) was not significantly different after wet storage than after dry storage at $0^{\circ} \mathrm{C}$. The vase life of tulips stored wet at $12.5^{\circ} \mathrm{C}$ was half that of flowers stored (wet or dry) at $0^{\circ} \mathrm{C}$, but was more than twice that of flowers stored dry at $12.5^{\circ} \mathrm{C}$ (Fig. 2).

IRIS'TELSTAR' There were no significant differences in vase life (determined by in-rolling of the banners followed by discoloration of the tepals) after wet or dry storage of iris at 0,5 , and $10^{\circ} \mathrm{C}$ (Fig. 3). Wet storage allowed iris to be stored at 15 and $20^{\circ} \mathrm{C}$, but was ac- 
Killian Daisy

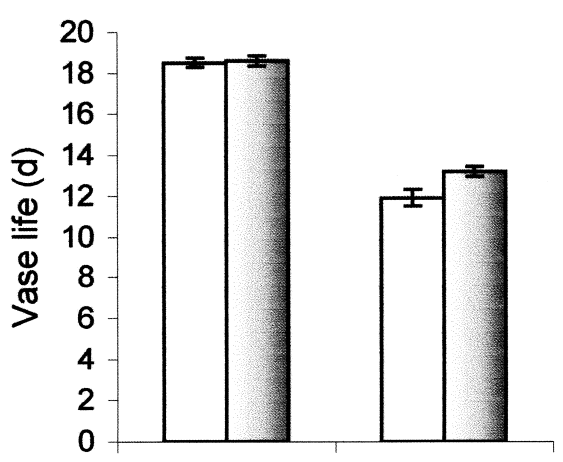

Tulip

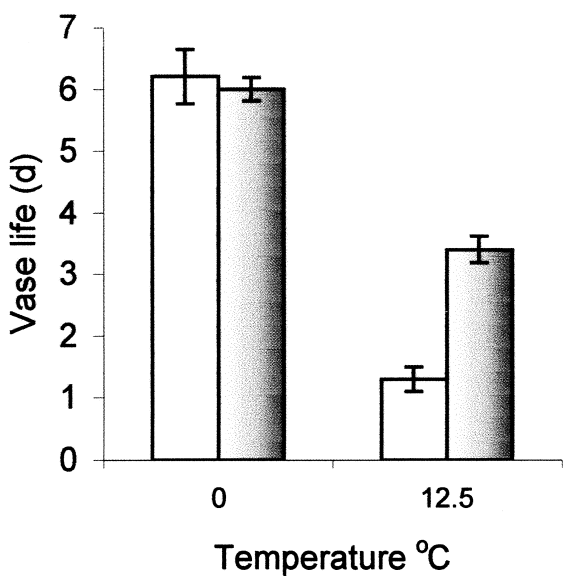

Fig. 2. Vase life of tulips and daisies at $20^{\circ} \mathrm{C}\left(68^{\circ} \mathrm{F}\right)$ after wet or dry storage at 0 or $12.5{ }^{\circ} \mathrm{C}(32$ or 54.5 $\left.{ }^{\circ} \mathrm{F}\right)$ for $6 \mathrm{~d}$. Error bars indicate the standard error of the means of six stems per treatment.

companied by a substantial reduction in subsequent vase life. Iris flowers did not survive dry storage at 15 and $20^{\circ} \mathrm{C}$ (Fig. 3).

Earnation-'Tapertal-White' There were no significant differences in vase life (terminated by in-rolling of the petals and growth of the gynoecium) after wet or dry storage for carnation at 0,5 , and $10{ }^{\circ} \mathrm{C}$ (Fig. 3). Wet storage allowed carnation to be stored at 15 and $20^{\circ} \mathrm{C}$, but carnations did not survive dry storage at those temperatures (Fig. 3).

The data obtained in the present study support the hypothesis that the benefits of wet storage are only observed in cut flowers when they are held at warmer storage temperatures (above $10{ }^{\circ} \mathrm{C}$ ). Nevertheless, the vase life after storage of all the cut flowers fell as the temperature during storage increased, whether the flowers were stored dry or in water (Figs 1, 2, and 3).
Previous researchers have examined the effects of dry and wet storage on the subsequent vase life of flowers, especially in cut carnations (Rudnicki et al. 1989). Wet storage is commonly recommended for storage periods of a few days (Hasegawa et al., 1976), while dry storage has been recommended for storage periods greater than 1 week. Goszczynska and Rudnicki (1982) successfully dry-stored bud-cut carnations for up to 6 months. However, De Hertogh and Springer (1977) found that iris kept better when stored wet, even for long periods. Additionally, Goszczynska et al. (1982) suggested that carnations harvested at commercial maturity performed better after cool storage if they had been held in water. Faragher et al. (1984) found that 'Mercedes' roses stored dry at 2.5 ${ }^{\circ} \mathrm{C}\left(36.5^{\circ} \mathrm{F}\right)$ for $10 \mathrm{~d}$ did not show a significant reduction of the water content of the petals compared to roses stored wet. The consensus of these reports is that wet storage is not necessary to prevent water loss at low temperatures. The variable results from previous research may reflect differences in water loss during dry storage and/or the influence of other factors such as botrytis (Botrytis sp.) infection

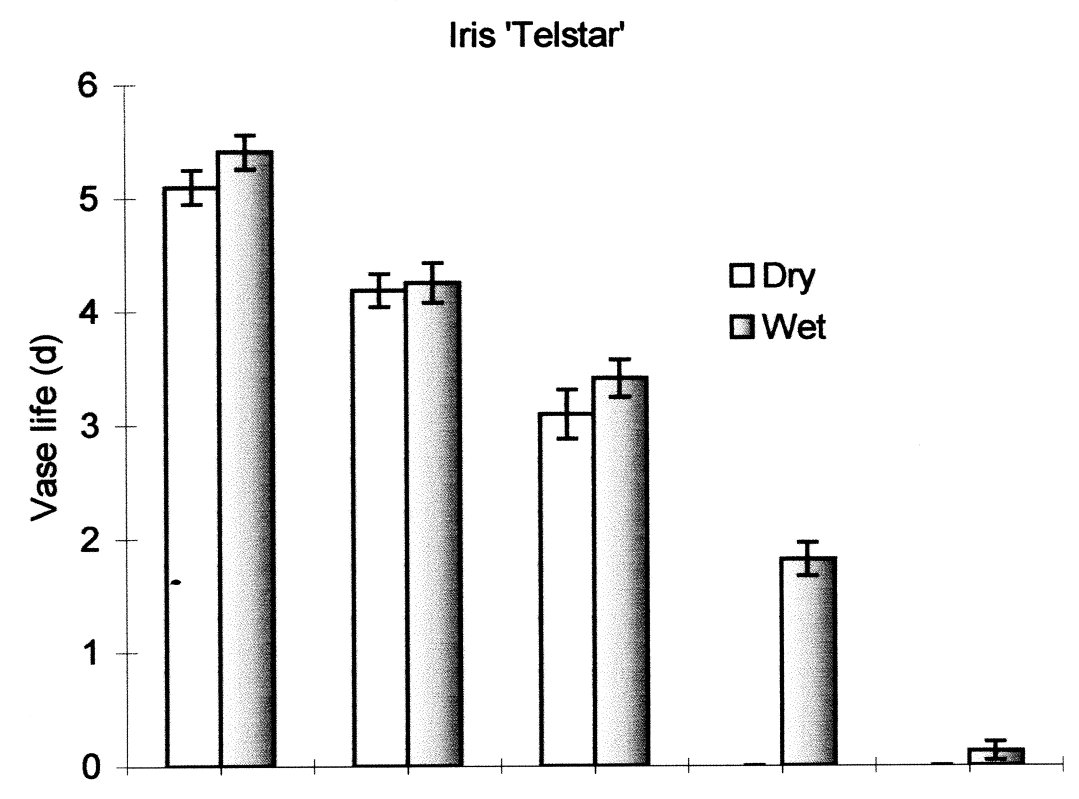

Carnation 'Imperial White'

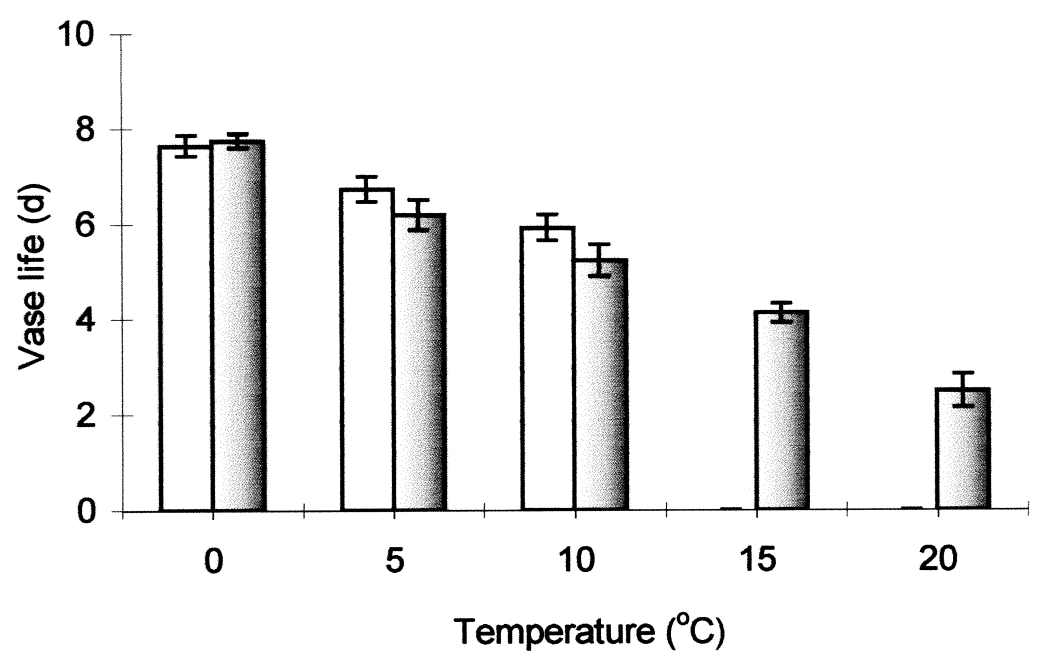

Fig. 3. Vase life of iris and carnations at $20^{\circ} \mathrm{C}\left(68^{\circ} \mathrm{F}\right)$ after wet or dry storage for $6 \mathrm{~d}$ at different temperatures. Error bars indicate the standard error of the means of 6 stems per treatment. 
that may be influenced by the humidity of the storage environment.

In our experiments, we found that storage of flowers in water was beneficial only at temperatures above $10^{\circ} \mathrm{C}$. However, wet storage did not prevent the respiration-related loss of vase life during storage at higher temperatures. Considering the higher volume and weight of flowers transported wet, which translates into higher costs of transportation and handling, our data clearly indicate that the industry should continue to transport flowers dry and should minimize losses by paying closer attention to maintaining proper storage temperatures and relative humidities. In circumstances where warmer transportation temperatures are unavoidable, wet storage will provide insurance against desiccation, and some additional vase life.

\section{Literature cited}

Cevallos, J.C. and M.S. Reid. 2001. Effect of storage temperature on respiration and vase life of selected flowers. Postharvest Biol. Technol. (in press).

De Hertogh, A.A. and G. Springer. 1977. Care and handling of spring bulb flowers and plants. Holland Flower-Bulb Tech. Serv. Bul. 4. Netherland Flower-Bulb Inst. Hillegen.
Faragher, J.D., S. Mayak, T. Tirosh, and A.H. Halevy. 1984. Cold storage of rose flowers: Effects of cold storage and water loss on opening and vase life of 'Mercedes' roses. Scientia Hort. 24:369-378.

Goszczynska, D.M. and R.M. Rudnicki. 1982. Long term storage of carnations cut at the green bud stage. Scientia Hort. 17:289-297.

Goszczynska, D.M., H. Pietrzkowska, and R.M. Rudnicki. 1982. Cold storage of carnations cut in bloom. Rosliny Ozdobne Ser. B 7:105-117.

Hasegawa, A., M. Manabe, M. Goi, and Y. Ihara. 1976. Studies on the keeping quality of cut flowers. Tech. Bul. Fac. Agr. Kagawa Univ. 27:85-94.

Maxie, E.C., D.S. Farnham, F.G. Mitchell, and N.F. Sommer. 1974. Temperature management effects on quality of carnation flowers and rosebuds. Calif. Agr. 28:67.

Rudnicki, R.M., D.M. Goszczynska, and T.M. Pisulewski. 1989. Bud opening and long term storage of spray carnations. Acta Hort. 261:265-270.

Thompson, J.F. and M.S. Reid. 1994. Temperature management during transportation of California cut flowers. Final Rpt. Calif. Cut Flower Comm. 